\title{
FAKTOR PENENTU PILIHAN BAHASA PADA MASYARAKAT MULTIBAHASA DI PASAR KEMAKMURAN KABUPATEN KOTABARU PROVINSI KALIMANTAN SELATAN
}

\author{
Kamal Hasuna dan Akhmad Humaidi
}

\author{
Pendidikan Bahasa dan Sastra Indonesia \\ STKIP PGRI Banjarmasin \\ Jalan Sultan Adam, Komplek H. Iyus, No. 18 RT.23 Banjarmasin, \\ Kalimantan Selatan. Kode pos 70121 \\ email: hkamalhasuna25@gmail.com
}

\begin{abstract}
ABSTRAK
Pemilihan bahasa dalam masyarakat multibahasa di pasar Kemakmuran Kotabaru merupakan fenomena yang menarik untuk dikaji dari perspektif sosiolinguistik. Fenomena tersebut bertemali buka hanya dengan aspek kebahasaan semata, melainkan juga dengan aspek sosial budaya. Penelitian ini dimaksudkan untuk mengungkap bagaimanaperspektif sosiolinguistis tentang pemilihan bahasa di pasar Kemakmuran Kabupaten Kotabaru Provinsi Kalimantan Selatan.

Untuk mengungkap akar permasalahan dalam penelitian ini digunakan pendekatan teoritis sosiolinguistik. Teknik pengumpulan data yang dipergunakan dalam penelitian ini ada dua macam, yaitu: metode simak dan metode cakap. Metode simak yang digunakan adalah teknik simak bebas libat cakap (SBLC), sedangkan metode cakap, yaitu teknik cakap semuka (CS), teknik cakap tidak tatap muka (CTS) dengan teknik rekam dan teknik catat. Adapun yang menjadi informan adalah masyarakat yang sedang menjalankan transaksi jual beli di pasar Kemakmuran Kabupaten Kotabaru. Data yang diambil dibatasi pada interaksi penutur yang berasal dari etnis yang berbeda.

Makalah ini akan mengkaji perspektif sosiolinguistik terhadap pemilihan bahasa di Pasar Kemakmuran berdasarkan teori Heymes yang dikenal dengan akronim SPEAKING, yaitu (1) setting and scene (latar dan suasana tutur), (2) participants (peserta tutur), (3) ends (tujuan tutur), (4) act sequence (topik/urutan tutur), (5) keys (nada tutur), (6) instrumentalities (sarana tutur), (7) norms (norma-norma tutur), dan (8) genre (jenis tutur).Pemilihan bahasa di pasar Kemakmuran Kabupaten Kotabaru dipengaruhi oleh berbagai faktor sosial dan budaya. Interaksi sosial dalam masyarakat multibahasa initerdiri dari beberapa bahasa atau ragam bahasa sehingga setiap penutur dituntut untuk mampu memilih secara tepat bahasa atau ragam bahasa yang sesuai dengan situasi komunikasi. Pemilihan bahasa ini tidak bersifat acak melainkan mempertimbangkan berbagai faktor. Pertama, karakteristik situasi kebahasaan ditandai dengan adanya kontak bahasa dan kontak dialek yang menjadikannya sebagai masyarakat bilingual atau multilingual.Sosiolinguistik melihat fenomena pemilihan bahasa sebagai fakta sosial dan menempatkannya dalam sistem lambang (kode), sistem tingkah laku budaya, serta sistem pragmatik. Dengan demikian, kajian sosiolinguistik menyikapi fenomena pemilihan bahasa sebagai wacana dalam peristiwa komunikasi dan sekaligus menunjukkan identitas sosial dan budaya peserta tutur.
\end{abstract}

Kata Kunci: faktor penentu, pilihan bahasa, multi bahasa

\section{PENDAHULUAN}

Bahasa tidak akan lepas hubungannya dari masyarakat. Melalui bahasa, sebuah masyarakat dapat menunjukkan identitasnya diantara masyarakat yang lain. Masyarakat Indonesia tentunya 
adalah masyarakatyang berbeda dengan kelompok sosial lainnya, hal ini dapat terlihat dari bahasa yang dimilikinya.

Untuk mempersatukan keanekaragaman bahasa daerah yang begitu kaya, Indonesia memiliki bahasa nasional yaitu Bahasa Indonesia. Selain itu, agar Indonesia tetap maju dalam informasi dan teknologi, maka Bahasa Inggris dan juga bahasa asing yang lain diajarkan di sekolah dan dipergunakan oleh masyarakat Indonesia sebagai bahasa komunikasi dengan masyarakat mancanegara. Maka dapat dijelaskan bahwa setiap bahasa yang dipergunakan di Indonesia yaitu bahasa daerah, bahasa Indonesia, dan bahasa asing memiliki kedudukan yang berbeda-beda yang tentunya saling mendukung satu dengan lainnya. Bahkan, di beberapa daerah di Indonesia ketiga bahasa tersebut dipakai dalam masyarakatnya. Salah satunya di pasar Kemakmuran Kabupaten Kotabaru Provinsi Kalimantan Selatan.

Masyarakat di Kabupaten Kotabaru merupakan masyarakat yang multi etnis, diantaranya adalah etnis Banjar, Jawa, Bajau, Bugis, Mandar, Madura, dan Dayak. Dalam berinteraksi social tentunya sangatlah beragam bahasa yang digunakan di masyarakat, khususnya dalam domain transaksi jual beli di pasar. Kondisi ini menuntut adanya pilihan ketika berinteraksi dengan mitra tutur yang berbeda. Tanpa sikap bahasa yang tepat, keberagaman itu sangat mungkin akan hilang dalam beberapa generasi di masa yang akan datang karena termakan oleh bahasa atau kelompok etnis yang lebih dominan. Keadaan ini sangat tidak diinginkan oleh semua pihak karena bahasa merupakan salah satu identitas utama sebuah etnis.

Fasold mendefinisikan bahwa pemilihan bahasa adalah sebuah perilaku atau dapat disebut dengan tindakan atau perilaku memakai bahasa terpilih berdasarkan situasi yang berbeda. Pemilihan bahasa bukan sesuatu yang sederhana. Fasold menjelaskan bahwapemilihan bahasa menurut Fasold tidak sesederhana yang kita bayangkan, yakni memilih sebuah bahasa secara keseluruhan (whole language) dalam suatu peristiwa komunikasi (Fasold, 1984:180). Dalam peristiwa komunikasi bahasa, bahasa tidak muncul begitu saja ia berhubungan dengan situasi sosial. Sejalan dengan apa yang jelaskan oleh Labov (1972:29) dalam situasi sosial sebenarnya seseorang tidak dapat semaunya saja membentuk kalimat. Di samping itu, Hudson menjelaskan bahwa bahasa tidak dapat digunakan lepas dari konteks dari masyarakat pemakainya (1996:4-5).

Berdasarkan latar belakang dan pemaparan teori yang telah dijelaskan di atas, maka peneliti ingin melakukan penelitian yang mendalam dan komprehensif, yaitu dengan menemukan, mendeskripsikan, menganalisis, dan menelaah berdasarkan teori yang relevan dan hasil penelitian terdahulu tentang pilihan bahasa pada masyarakat multibahasa di pasar Kemakmuran Kabupaten Kotabaru Provinsi Kalimantan Selatan. 


\section{METODE}

Jenis penelitian ini adalah penelitian kualitatif dan orientasi teoretisnya sosiolinguistik. Adapun pendekatan kualitatif adalah pendekatan yang bermaksud untuk memahami fenomena tentang apa yang dialami oleh subjek penelitian misalnya perilaku, persepsi, motivasi, tindakan, dan lain-lain secara holistik dan dengan cara deskripsi bentuk kata-kata dan bahasa pada suatu konteks khusus yang alamiah dan dengan memanfaatkan berbagai metode ilmiah. Pendekatan kualitatif merupakan usaha memahami fenomena sosial kebahasaan yang diteliti. Penelitian kualiatif ini merupakan usaha memahami fenomena kebahasaan lain yang tengah diteliti. Penelitian kualitatif sifatnya deskriptif karena hasil penelitian berupa deskripsi dari gejala-gejala yang diamati. Alasan penelitian ini menggunakan pendekatan kualitatif karena data yang digunakan penelitian ini, berupa percakapan pada domain transaksi jual beli di pasar Kemakmuran Kabupaten Kotabaru.

Penelitian ini dilaksanakan di pasar Kemakmuran Kabupaten Kotabaru Provinsi Kalimantan Selatan. Pasar ini merupakan pasar tradisional yang manjadi pusat jual beli masyarakat kelas menengah ke bawah di kecamatan Pulau Laut Utara mulai dari kebutuhan pokok, pakaian, berbagai peralatan rumah tangga, dan sebagainya. Lokasi ini dipilih karena masyarakat yang melakukan aktivitas jual beli berasal dari berbagai etnis dengan bahasanya masing-masing.

Data penelitian ini adalah data dalam bentuk tuturan yang dituturkan oleh masyarakat dalam domain transaksi jual beli di Pasar Kemakmuran pada saat berkomunikasi yaitu berupa kata-kata, kalimat, dan ungkapan-ungkapan untuk mengetahui kondisi pemakaian bahasa. Data ini diperoleh dengan merekam peristiwa tutur.

Penelitian ini melibatkan penduduk atau masyarakat multietnis yang ada di pasar Kemakmuran Kabupaten Kotabaru sebagai sumber data. Sumber data penelitian ini berasal dari penjual dan pembeli sebagai informan yang digali informasinya. Ketika berinteraksi informan yang dipilih harus berasal dari etnis yang berbeda. Bila tidak, percakapan itu tidak dipertimbangkan sebagai data penelitian.

Teknik pengumpulan data yang dipergunakan dalam penelitian ini ada dua macam, yaitu: metode simak dan metode cakap.

a. Metode simak yang digunakan adalah teknik simak bebas libat cakap (SBLC).

b. Metode cakap yang digunakan adalah teknik cakap semuka (CS), teknik cakap tidak tatap muka (CTS), teknik rekam dan teknik catat.

Untuk lebih jelasnya dapat dilihat pada Tabel berikut 
Tabel Teknik Pengumpulan Data

teknik pengumpulan data

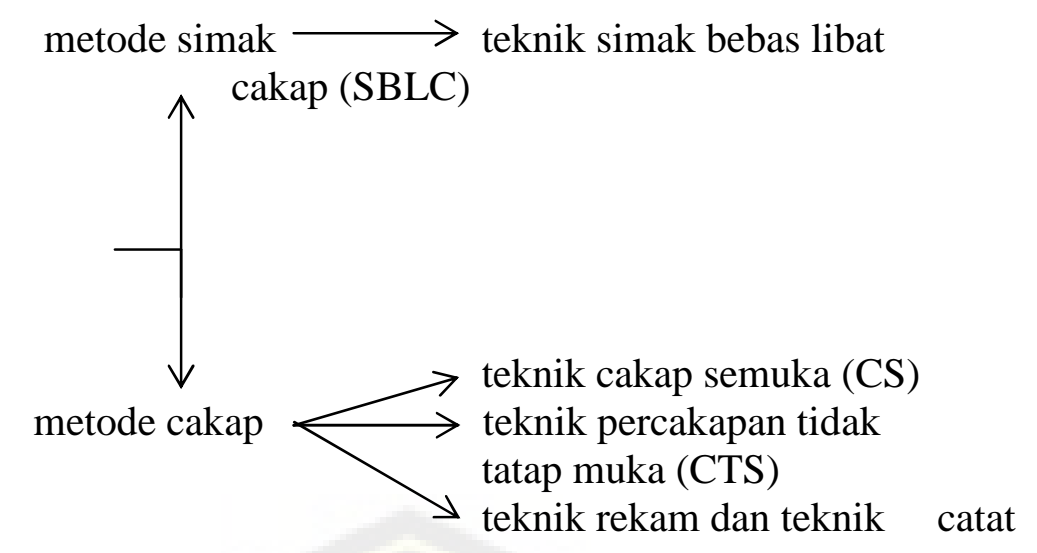

Penelitian ini menggunakan teknik analisis deskriptif-kualitatif dan interpretatif. Artinya penulis mendeskripsikan gejala-gejala dan fakta-fakta pemilihan bahasa pada masyarakat multi bahasa. Proses analisis data dimulai dengan menelaah seluruh data yang tersedia dari berbagai sumber. Setiap data yang diperoleh dari pengumpulan data, hasil wawancara, observasi, dan dokumentasi dikategorikan dalam tema pokok pemasalahan yang sesuai. Selanjutnya data dan informasi yang diperoleh dari lapangan disajikan dalam bentuk uraian deskriptif yang didukung oleh tabel data.

Proses analisis data dalam penelitian ini diawali dengan menelaah seluruh data yang tersedia dari berbagai sumber, yakni teknik simak bebas libat cakap (SLBC), teknik cakap semuka (CS), teknik percakapan tidak tatap muka (CTS). Analisis data dilakukan sejak penelitian berlangsung dengan cara merekam berbagai peristiwa tutur yang terjadi. Melalui CS dan CTS akan ditemukan perpektif sosiolinguistis, kategori pemilihan, dan faktor penentu pilihan bahasa. Data dan informasi yang diperoleh di lapangan yang sesuai dengan masalah penelitian, diseleksi, kemudian dideskripsikan secara kualitatif.

\section{HASIL DAN PEMBAHASAN}

Pasar Kemakmuran berada di Kelurahan Kotabaru Tengah, Kecamatan Pulau Laut Utara, Kabupaten Kotabaru, Kalimantan Selatan. Para pedagang di pasar ini terdiri dari berbagai suku bangsa dengan bahasanya masing-masing. Di pasar ini, penelitian ini berhasil mengidentifikasi ada suku Banjar, Bugis, Jawa, Mandar, Bajau, Madura, Bima, dan Dayak. Dari delapan suku bangsa tersebut, suku Banjar dan Bugis mendominasi para pedagang di pasar tersebut.

Pasar ini memiliki luas 41.386,42 $\mathrm{M}^{2}$ dengan enam blok, yaitu blok B/F, blok C, blok D, blok E, blok G, dan pasar ikan. Pasar ini tergolong pasar tradisional karena barang-barang yang diperjualbelikan masih murah dan belum dikemas dengan cara modern. Namun, di bagian depannya 
berdiri bangunan yang lebih modern, yakni Pasar Limbur Raya. Meskipun bangunannya lebih besar, bagian dalam pasar ini tidak seramai, pasar Kemakmuran karena barang-barang yang dijual kurang bervariasi. Selain itu, lantai dua hanya diisi oleh para pedagang emas. Peta pasar Kemakmuran dapat diamati pada gambar berikut ini.

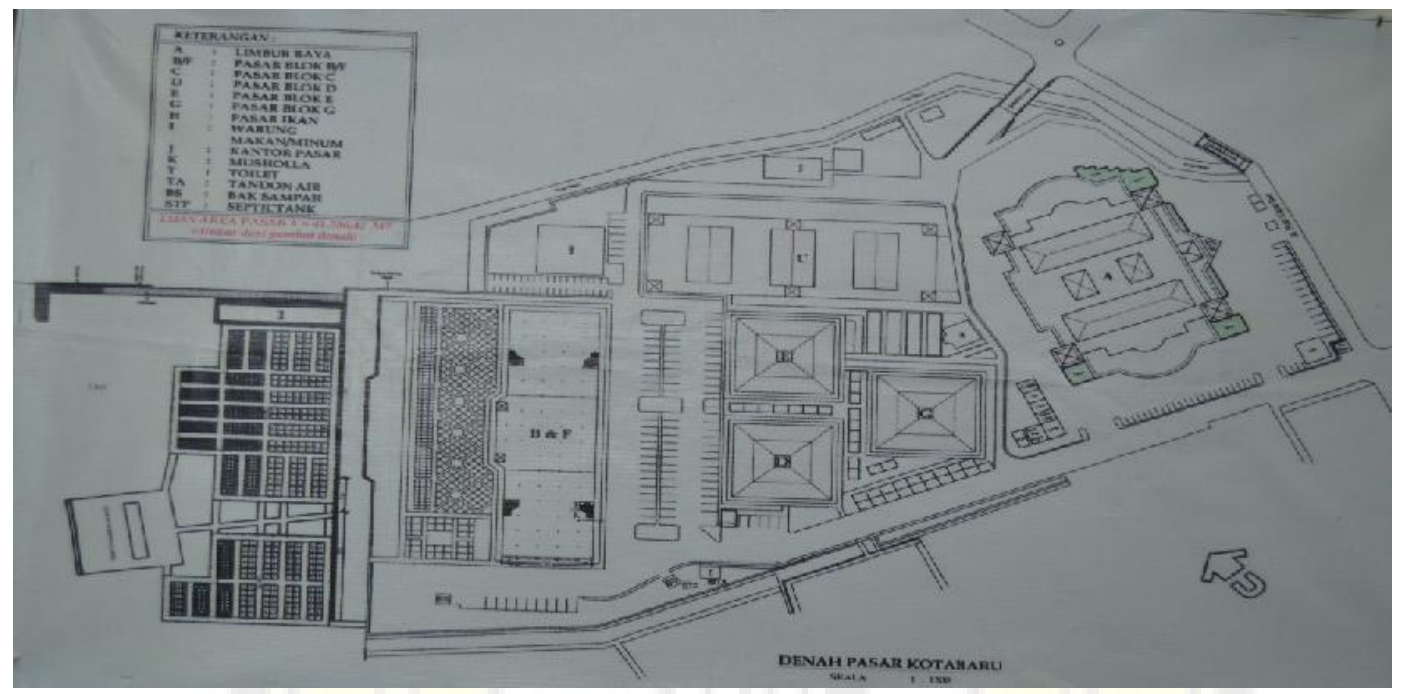

Waktu transaksi yang paling ramai terjadi antara jam 6 hingga 7.30 pagi yang sering disebut pasar subuh. Lokasinya berada di pelataran gedung blok B\&F dan blok I yang menjual sayur, ikan, dan kue-kue basah. Para pembeli memadati waktu ini sebelum mereka mulai beraktivitas pagi harinya. Keuntungannya bagi ibu-ibu rumah tangga ialah mereka akan punya waktu untuk mempersiapkan makanan baik ikan, sayur, maupun sekadar membeli kue-kue basah untuk keluarganya. Adapun bagi pedagang yang mengelola warung makan, mereka bisa membeli bahanbahan mentah dengan lebih murah agar bisa diolah untuk dijual kembali. Barang-barang yang dijual juga masih segar dan banyak sehingga waktu yang paling tepat untuk berbelanja ialah waktu ini.

Namun, pada sore hari pasar ini kembali dipadati di blok I, yakni tempat jual beli ikan. Pada waktu ini, para nelayan mengantarkan hasil tangkapannya kepada para pedagang di blok tersebut. Ikan-ikan yang dijual masih segar dan banyak sehingga dapat dipastikan kualitas barang yang dijual lebih baik dibandingkan waktu-waktu yang lain. Di samping itu, para pembeli yang bekerja dari pagi hingga sore hari juga bisa mampir ke lokasi ini sebelum pulang untuk membawa ikan yang akan dimakan pada malam harinya.

Pedagang ikan di blok I terdiri dari dua suku bangsa utama, yatiu Bugis dan Bajau. Suku Bugis cenderung memiliki tingkat ekonomi yang lebih tinggi karena kapal nelayan yang mereka miliki lebih besar sehingga ikan-ikan yang mereka tangkap sangat beragam, seperti tongkol, kerapu, tenggiri, dan sebagainya. Adapun suku Bajau, umumnya masih rendah tingkat ekonominya sehingga ikan-ikan yang dijual hanya yang hidup di wilayah pesisir. Namun, terkadang mereka juga menjual ikan-ikan laut perariran dalam dengan membeli kepada penjual lain, meskipun dalam jumlah yang sedikit. 
Selain dua waktu tersebut, hari Jumat dan Minggu juga merupakan waktu transaksi yang paling ramai. Hari Jumat berlangsung dari pagi hari hingga sekitar pukul 10.00 WITA. Hari Jumat memang telah menjadi kebiasaan masyarakat di nusantara untuk bertransaksi jual beli sehingga seringkali disebut juga hari pasar. Selain itu, hari Minggu pagi juga menjadi waktu transaksi yang selalu dipadati oleh pembeli. Para pegawai baik pemerintahan maupun swasta tidak bekerja pada hari ini sehingga mereka memanfaatkannya untuk membeli berbagai kebutuhan pokok untuk diolah kembali bagi keluarganya.

Penelitian ini dilaksanakan dalam dua tahap. Tahap pertama, peneliti terlebih dahulu melakukan observasi untuk mengamati situasi secara umum dan menentukan strategi untuk pengumpulan data. Peneliti juga berkoordinasi dengan pengelola pasar untuk menemukan para pedagang yang akan dijadikan informan. Penentuan informan didasarkan pada suku bangsa yang ada di pasar ini. Informan mengambil perwakilan beberapa orang dari setiap suku bangsa, yaitu Banjar, Bugis, Jawa, Mandar, Bajau, Madura, Bima, dan Dayak.

Peneliti menggunakan dua teknik pengumpulan data, yaitu metode simak, yakni teknik simak bebas libat cakap (SBLC) dan metode cakap, yaitu teknik cakap semuka (CS), teknik cakap tidak tatap muka (CTS), teknik rekam dan teknik catat. Peneliti mewawancarai informan dengan pertanyaan terstruktur untuk mengetahui gambaran umum bahasa yang mereka gunakan saat bertransaksi jual beli. Pada hari selanjutnya, peneliti merekam percakapan para informan tersebut sebagai data percakapan.

Setelah data terkumpul, peneliti melakukan transkripsi data agar analisis dapat lebih mudah dilakukan. Data tersebut akan diklasifikasikan sesuai dengan rumusan masalah yang telah ditetapkan, yaitu perspektif sosiolinguistis, kategori, dan faktor penentu pemilihan bahasa. Data ini masih memerlukan validasi dari penutur dan ahli untuk memastikan kebenaran data. Analisis data akan mengalami perbaikan ketika terjadi ketidaksesuaian antara deskripsi peneliti dan data yang sebenarnya.

\section{Perspektif sosiolinguistis Pemilihan Bahasa di Pasar Kemakmuran}

Perspektif sosiolinguistis pemilihan bahasa yang digunakan dalam pemilihan bahasa di pasar Kemakmuran Kabupaten Kotabaru mengacu pada pandangan Hymes yang mengidentifikasi faktor luar bahasa berdasarkan delapan komponen peristiwa tutur. Pandangan ini dikenal dengan akronim SPEAKING yang merupakan singkatan dari Setting and scene (latar dan suasana tutur), (2) participants (peserta tutur), (3) ends (tujuan tutur), (4) act sequence (topik/ urutan tutur), (5) keys (nada tutur), (6) instrumentalities (sarana tutur), (7) norms (norma-norma tutur), dan (8) genre (jenis tutur). Pembahasannya adalah sebagai berikut.

1. Setting and scene (latar dan suasana tutur) 
Latar dan suasana tutur menentukan bagaimana percakapan terjadi. Data yang digunakan dalam penelitian ini berasal dari percakapan di pasar. Latar ini merupakan tempat transaksi jual beli berbagai kebutuhan.

\section{Participants (peserta tutur)}

Peserta tutur pada percakapan ini melibatkan pembeli dengan penjual, pembeli dengan pembeli, dan penjual dengan penjual. Mitra tutur sangat menentukan bahasa yang digunakan oleh penutur. Posisi sosial yang tinggi akan membuat seseorang lebih berhati-hati dalam memilih variasi, bahkan bahasa tertentu.

\section{Ends (tujuan tutur)}

Tujuan tutur antara para partisipan ialah mendapatkan komoditas yang mereka inginkan. Bagi pembeli, mereka menginginkan barang dengan kualitas bagus dengan harga yang murah, sedangkan penjual, mereka menginginkan barang yang dijual memiliki nilai yang tinggi dan laku dalam jumlah yang besar

\section{Keys (nada tutur)}

Setiap penjual atau pembeli yang berbeda suku bangsa umumnya menggunakan bahasa Banjar sebagai alat komunikasi. Meskipun demikian, logat atau aksen mereka tidak bisa dihilangkan dan jelas terlihat pada nada tuturannya.

\section{Instrumentalities (sarana tutur)}

Sarana tutur yang digunakan oleh para partisipan di pasar ialah lisan. Konsekuensi yang muncul ialah percakapan akan berlangsung dalam kalimat-kalimat yang singkat dan cepat.

6. Norms (norma-norma tutur)

Setiap suku bangsa umumnya memiliki norma tuturnya masing-masing. Akan tetapi, norma tutur tersebut tidak terlalu signifikan ketika diterapkan dalam percakapan pada transaksi jual beli. Selain itu, setiap penutur umumnya dapat memaklumi gaya tutur mitra tuturnya ketika di pasar.

\section{Kategori Pemilihan Bahasa di PasarKemakmuran}

Suku bangsa di Pasar Kemakmuran cukup beragam, seperti bahasa Banjar, Bugis, Mandar, Bajau, Jawa, dan sebagainya. Meskipun demikian, berbagai etnis ini cenderung memilih bahasa Banjar untuk berkomunikasi dengan berbagai alasan. Suku yang berbeda berusaha untuk terus menggunakan bahasa Banjar ketika berkomunikasi, walaupun aksen/logat mereka tetap jelas terlihat.

Akan tetapi, bila mitra tutur mereka berasal dari suku yang sama, mereka akan memilih bahasa yang sama. Misalnya, bila mereka sesama suku Jawa, maka bahasa yang digunakan ialah bahasa Jawa. Namun, hal ini hanya terjadi bila mereka telah mengetahui satu sama lain. Pemilihan ini dilakukan untuk mendapatkan keakraban sesama penutur. Terkait dengan hal tersebut, hal yang 
menarik ialah sebagian data menunjukkan bahwa suku bangsa tertentu berusaha menggunakan bahasa mitra tuturnya agar lebih akrab, baik pembeli kepada penjual atau sebaliknya.

Akan tetapi, setiap penutur tidak asal mencoba karena beberapa bahasa tertentu memiliki masyarakat bentuk yang sama, tetapi makna yang berbeda. Oleh sebab itu, beberapa suku bangsa cenderung menghindari usaha ini, seperti suku Mandar enggan berbahasa Bajau begitu juga sebaliknya karena takut salah bicara. Begitu juga bahasa Bugis dan Mandar, seperti kata busi bagi suku Bugis bermakna..., sedangkan bagi suku Mandar bermakna ....

Pemilihan bahasa yang berhasil ditemukan dalam penelitian ada ada tiga, yaitu 1) variasi bahasa yang sama, 2) alih kode, dan 3) campur kode. Bentuk pemilihan ini dapat diamati pada kutipan percakapan berikut.

Pembicara 1: Goncing lamari, goncing kamara. Maccue maneng koro.

'Kunci lemari, kunci kamar. Ikut di sana semua'

Pembicara 2: Matu mega dalleta. Mega dalleta matu. 'banyak rezeki nanti Anda. Banyak rezeki nanti Anda'

Pembicara 1: Makki telluka sappai koro he. Kipabbalu bale degaga uruntu. Tiga kali saya mencari disitu. Di penjual ikan tidak dapat'

Pembicara 2: Bah de natabbe itu.

'Bah tidak hilang itu'

Pembicara 1: Kurang arua pulona na.

'Kurang delapan puluh dari'

Pembicara 2: na tellu juta.

'Dari tiga juta'

Pembicara 1: na dua juta.

'Dari dua juta'

Pembicara 1: Kurang dua puluh ribu eh delapan puluh ribu. Delapan puluh. Tujuh, Eh delapan puluh ribu. Dua juta.

Pembicara 2: Berarti sianu sijuta arua ratu' na lebbi.

'Berarti sekian, satu juta delapan ratus lebih'

Pembicara 1: Laeng. Engka to dui duappulona. Makkitelluka sappai degaga

'Lain. Ada juga uang dua puluhnya. Tiga kali sudah mencari tidak ada'

Kutipan tersebut merupakan percakapan antarpembeli yang berasal dari suku Bugis. Keduanya memilih bahasa Bugis sebagai media komunikasi, tetapi pada bagian tertentu pembicara 1 melakukan alih kode dari bahasa Bugis ke bahasa Indonesia, yakni dengan mengatakan "Kurang dua puluh ribu eh delapan puluh ribu. Delapan puluh. Tujuh, Eh delapan puluh ribu. Dua juta." Penutur mengganti bahasanya secara utuh mulai dari pemilihan kata hingga struktur kalimatnya. Tindakan ini diambil secara spontan, tetapi dengan tujuan yang jelas, yakni memperjelas maksud yang ingin disampaikan.

Bentuk ini berbeda dengan campur kode yang hanya mengambil serpihan-serpihan dari bahasa lain ketika bercakap-cakap. Hal ini dapat diamati pada kutipan berikut ini.

Penjual I : Bule, batu dacing pian mana bule?

'Bule, batu asah Anda di mana bule?'

Penjual II $\quad$ : di rumah, saya ndak jualan kecambah

' di rumah, saya mau jualan kecambah' 


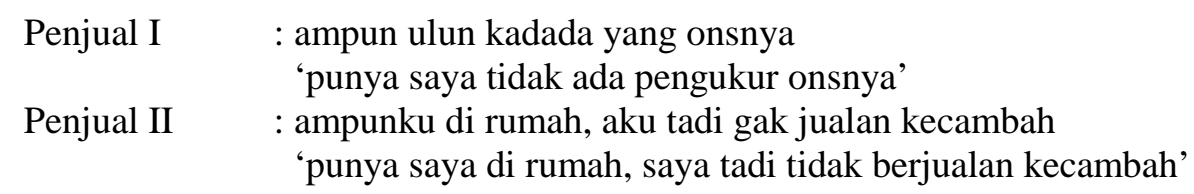

Percakapan ini dilakukan oleh penjual dari suku Banjar dan penjual dari suku Jawa. Pembeli mengambil serpihan dari bahasa Jawa dengan menggunakan kata ganti yang berasal dari bahasa Jawa, yaitu bule. Kata ini dari bahasa asalnya bial diterjemahkan menjadi bibi, tetapi untuk memahaminya perlu pengetahuan yang lebih dalam karena acuannya kepada adik dari ibu atau orang yang dihormati dengan usia lebih muda. Kata ini dalam bahasa Jawa beriringan dengan kata untuk mengacu kepada kakak ibu atau orang yang dihormati dengan usia yang lebih tua, yakni bude. Kata-kata berasal dari gabungan kata cilik yang berarti kecil untuk bule, dan gede yang berarti besar untuk bude. Fenomena ini tergolong dalam kategori campur kode karena penutur hanya memasukkan serpihan-serpihan kata, tanpa diikuti oleh struktur bahasanya.

Tindakan ini dilakukan dengan tujuan untuk menumbuhkan rasa akrab antara kedua penutur. Dengan cara ini, kerja sama akan lebih mudah terjalin sehingga kegiatan ekonomi akan lebih mudah terjalin. Pada percakapan yang sama, penutur dari Banjar memilih variasi bahasa yang lebih sopan dari bahasa asalnya. Penutur menggunakan kata ganti orang kedua dengan kata pian yang lebih sopan, bukan ikam yang digunakan untuk percakapan dengan mitra tutur setara. Hal yang sama juga dilakukan dengan penggunakan kata ganti orang pertama ulun bukan aku yang digunakan untuk situasi yang lebih sopan.

Berdasarkan percakapan tersebut, sebenarnya penutur suku Jawa tetap menggunakan bahasanya sendiri. Dia menggunakan kata ndak dan gak untuk kata tidak. Selain itu, selain bahasa Indonesia, dia juga menyisipkan kata dari bahasa Banjar dengan kata ampunku yang bermakna milikku.

Berdasarkan percakapan tersebut, sebenarnya penutur suku Jawa tetap menggunakan bahasanya sendiri. Dia menggunakan kata ndak dan gak untuk kata tidak. Selain itu, selain bahasa Indonesia, dia juga menyisipkan kata dari bahasa Banjar dengan kata ampunku yang bermakna milikku. Penyisipan ini merupaan satu bentuk interferensi bahasa pertamanya, yakni bahasa Jawa terhadap bahasa kedua yang digunakan, yakni bahasa Indonesia. Penutur tampaknya kurang menguasai bahasa Banjar sehingga dia lebih memilih bahasa Indonesia informl yang bercampur dengan bahasa daerahnya. Kategori pemilihan bahasa ini sangat tergantung dari berbagai variabel. Bila mengacu pada teori Hymes, variabel itu mengacu pada akronim SPEAKING yang telah dibahas sebelumnya.

\section{SIMPULAN}

Berdasarkan pembahasan yang telah dilakukan, penelitian ini menemukan tiga simpulan sesuai dengan rumusan masalah yang telah ditetapkan sebelumnya. Simpulannya adalah sebagai berikut. 
1. Perspektif sosiolinguistis terhadap pemilihan bahasa di Pasar Kemakmuran terdiri dari delapan komponen peristiwa tutur, yaitu Setting and scene (latar dan suasana tutur), (2) participants (peserta tutur), (3) ends (tujuan tutur), (4) act sequence (topik/ urutan tutur), (5) keys (nada tutur), (6) instrumentalities (sarana tutur), (7) norms (norma-norma tutur), dan (8) genre (jenis tutur).

2. Kategori pemilihan bahasa di Pasar Kemakmuran ada tiga, yaitu variasi bahasa yang sama, alih kode, dan campur kode. Dari tiga kategori tersebut, penutur akan menentukan bentuk tuturannya berdasarkan komponen-komponen peristiwa tutur yang telah disebutkan sebelumnya.

3. Faktor penentu pemilihan bahasa di Pasar Kamakmuran ada empat, yaitu 1) partisipan, 2) latar (waktu dan tempat) dan situasi, 3) topik percakapan, dan 4) fungsi interaksi. Berdasarkan faktor tersebut penguasaan bahasa partisipan menjadi penentu seorang penutur melakukan pemilihan bahasa. Namun, bahasa dominan, yakni bahasa Banjar juga menjadi faktor utama yang mempengaruhi cara bertutur penjual maupun pembeli. Bahasa ini menjadi media komunikasi yang paling efektif untuk mempermudah jual beli di Pasar Kemakmuran.

\section{SARAN}

1. Pemilihan bahasa sangat dipengaruhi oleh bahasa dominan yang ada di suatu wilayah. Pada Pasar Kemakmuran, bahasa Banjar mendominasi bahasa-bahasa lain yang hidup. Kondisi ini sedikit demi sedikit akan menggeser bahasa-bahasa lain sehingga bahasa yang tidak mampu bertahan akan mati. Oleh sebab itu, perlu ada upaya untuk mempertahankan bahasa-bahasa yang ada di Kabupaten Kotabaru Provinsi Kalimantan Selatan.

2. Penelitian selanjutnya perlu menindaklanjuti hasil temuan ini dengan menemukan pola pemertahanan bahasa yang kuat. Berdasarkan hasil penelitian yang telah dilakukan, bahasa yang memiliki pemertahanan yang cukup tinggi ialah bahasa Bajau. Penelitian selanjutnya perlu menemukan bagaimana masyarakatnya berhasil mempertahankan bahasanya sehingga dapat dijadikan sebagai contoh untuk bahan pertimbangan pengambil kebijakan untuk mempertahankan bahasa-bahasa lain yang hidup di Kabupaten Kotabaru Provinsi Kalimantan Selatan.

3. Pemilihan bahasa menjadi titik awal untuk memetakan kondisi sosiolinguistis di Kabupaten Kotabaru Provinsi Kalimantan Selatan. Penelitian-penelitian selanjutnya terkait pemetaan terssebut perlu diakukan, seperti pergeseran bahasa, perubahan bahasa, pembakuan bahasa, kebijakan dan politik bahasa, pengembangan kamus, pengembangan buku ajar, hingga perancangan kurikulum bahasa-bahasa daerah di wilayah tersebut. 


\section{DAFTAR RUJUKAN}

Bell, R.T. 1976 Sociolinguistics: Goals, Approaches, and Problems. London: Bastford.

Dittmar, Norbert. 1976 Sociolinguistics. London: Edwar Arnold

Fasold, Ralph. 1984 The Sociolinguistics of Society. Oxford: Basil Blackwell. 1990 The Sociolinguistics of Language. Oxford: Basil Blackwell.

Fishman, Joshua A. 1972 The Sociology of Language. Rowley: Newbury House.

Groesjean, Fracois. 1982. Life with Two Languages. Cambridge: Harvard University Press.

Gumperz, John danHymes, Dell (eds.). 1972. Direction in Sociolinguistics. New York: Holt, Rinehart, and Winston.

Holmes, Janet. 1992 An Introduction to Sociolinguistics. New York: Longman.

Hudson, R.A. 1996 Sociolinguistics (Second Edition). Cambridge: Cambridge University Press.

Hymes, Dell, ed. 1980. Foundations in Sociolinguistics An Ethnographics Approach. Philadelpia: University of Pennsylvania Press.

Kartomihardjo, Soeseno. 1988. Bahasa Cermin Kehidupan Masyarakat. Jakarta: Depdikbud.

Labov, Williams 1972. Sociolinguistic Patterns. Philadelphia: University of Pennsylvania Press.

Nababan, P.W.J. 1993. Sosiolinguistik: Suatu Pengantar. Jakarta: PT Gramedia.

Wardhaugh, Ronald. 1986. An Introduction to Sociolinguis-tics. Oxford: Basil Blackwell.

Wijana, I DewaPutu. 1997.Linguistik, Sosiolinguistik, dan Pragmatik. Makalah dalam Temu Ilmiah Bahasa dan Sastra di Balai Penelitian Bahasa, Yogyakarta. 